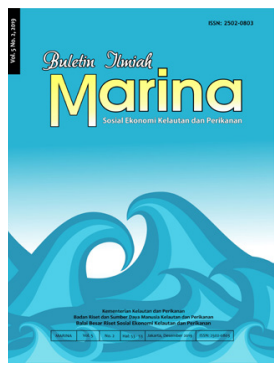

BULETIN ILMIAH MARINA

SOSIAL EKONOMI KELAUTAN DAN PERIKANAN

http://ejournal-balitbang.kkp.go.id/index.php/mra

p-ISSN: 2502-0803

e-ISSN: 2541-2930

Nomor Akreditasi: 10/E/KPT/2019

\title{
PEMBERDAYAAN PERIKANAN DI KABUPATEN LOMBOK TIMUR PROVINSI NUSA TENGGARA BARAT
}

\section{Fisheries Empowerment in East Lombok Regency, Nusa Tenggara Barat Province}

\author{
*Maulana Firdaus, Nensyana Shafitri, dan Cornelia Mirwantini Witomo \\ Balai Besar Riset Sosial Ekonomi Kelautan dan Perikanan \\ Gedung BRSDM KP I Lt. 4 \\ Jalan Pasir Putih Nomor 1 Ancol Timur, Jakarta Utara, Indonesia \\ Telp: (021) 64711583 Fax: 64700924
}

Diterima tanggal: 17 Juni 2020 Diterima setelah perbaikan: 8 November 2020

Disetujui terbit: 21 Desember 2020

\begin{abstract}
ABSTRAK
Program pembangunan ekonomi nasional berbasis perikanan dan pedesaan secara langsung maupun tidak langsung diharapkan dapat menanggulangi permasalahan ketimpangan wilayah dan keterbatasan modal usaha perikanan. Sejak tahun 2010, Kementerian Kelautan dan Perikanan Indonesia telah melaksanakan program pemberdayaan kepada kelompok nelayan dan kelompok pembudi daya ikan. Tujuan dari penelitian ini adalah untuk menganalisis kinerja program pemberdayaan masyarakat melalui skema Program Nasional Pemberdayaan Masyarakat Mandiri Kelautan dan Perikanan (PNPM Mandiri KP) pada perikanan tangkap dan budi daya di Kabupaten Lombok Timur. Penelitian ini dilaksanakan pada tahun 2016 di Kabupaten Lombok Timur. Data primer dikumpulkan dengan cara survei dan informan dipilih secara purposive sampling dilengkapi dengan data sekunder dari berbagai sumber. Analisis deskriptif kuantitatif digunakan untuk melakukan analisis data. Hasil penelitian menunjukkan bahwa aspek penentuan lokasi bantuan harus diprioritaskan untuk lokasi yang sebagian masyarakatnya bermata pencaharian utama usaha perikanan. Program bantuan perikanan tangkap memiliki peluang keberhasilan yang lebih besar dibandingkan dengan program bantuan perikanan budi daya. Ini dapat dilhat dari dampak program dan potensi keberlanjutan program tersebut.
\end{abstract}

Kata Kunci: pemberdayaan masyarakat; perikanan; kinerja program; Lombok Timur

\begin{abstract}
The National economic development program based on fisheries and rural area is directly or indirectly address to disparity problem of the region and financial limitation in fisheries. Since 2010 , Ministry for Marine Affairs and Fisheries (MMAF) of Indonesia had implemented the empowerment program for fishermen and farmer groups. This study aimed to analyze the performance of community empowerment program namely the National Program for Community Empowerment in Marine and Fisheries (or PNPM Mandiri KP) for capture fisheries and aquaculture in East Lombok Regency. West Nusa Tenggara Province. This research was conducted in 2016. Primary data were collected through a survey and key informants were selected purposively, and supported by secondary data from various sources. Quantitative descriptive analysis was used for data analysis. The results shows that the aspect of location should be prioritized for the community who have major livelihood activity in fisheries sector. The program in capture fisheries have a greater opportunity of successful compared with aquaculture programs. It can be seen from impac of the program and potency of the program sustainability.
\end{abstract}

Keywords: community empowerment; fishery; program performance; East Lombok 


\section{PENDAHULUAN}

\section{Latar Belakang}

Sasaran pembangunan nasional dan regional di Indonesia adalah menciptakan pertumbuhan ekonomi dan pemerataan kesejahteraan kehidupan masyarakat secara adil di seluruh wilayah Indonesia (Budianta, 2010). Pertumbuhan ekonomi yang tinggi tidak hanya dapat meningkatkan kesejahteraan, tetapi juga dapat memperlebar kesenjangan atau ketimpangan antardaerah maupun antar golongan masyarakat (Bagchi \& Svejnar, 2015; Mahadevan \& Suardi, 2019). Pencapaian kesejahteraan masyarakat Indonesia tidak akan terlepas dari konteks kesenjangan pendapatan dan kemiskinan (Afdillah, Harahap, \& Marliyah, 2016; Sholihah \& Kustanto, 2017). Kemiskinan telah menjadi fokus dan kajian yang menarik bagi banyak kalangan, mulai dari masyarakat awam, birokrat, politikus, pemimpin agama hingga kalangan akademisi (Maipita, Jantan, \& Razak, 2010). Pengentasan kemiskinan merupakan persoalan yang sampai saat ini belum bisa untuk diatasi pemerintah pusat dan daerah pada khususnya. Karakteristik kemiskinan ini semakin memburuk karena adanya program-program pemerintah yang tidak tepat sasaran dalam memberdayakan keluarga miskin (Maifizar, 2018).

Salah satu indikasi persoalan ketimpangan wilayah adalah persoalan daerah tertinggal dan masalah ketimpangan pembangunan yang disebabkan oleh disparitas wilayah. Daerah tertinggal ditandai oleh aksesibilitas yang rendah terhadap pelayanan sarana dan prasarana ekonomi, alokasi anggaran yang rendah, sumber daya alam yang terbatas, dan letak geografis yang relatif terpencil (Aziz, 1994; Sartika, Balaka, \& Rumbia, 2016). Selama ini, ketimpangan wilayah tidak terlepas dari sentral pembangunan yang berada di pulau, sehingga pembangunan wilayah lainnya khususnya Indonesia bagian timur jauh tertinggal. Ketimpangan wilayah juga disebabkan oleh perencanaan yang tidak sesuai dengan potensi wilayah (Sumaryadi, 2005).

\footnotetext{
Kabupaten Lombok Timur di Provinsi Nusa Tenggara Barat masih menghadapi masalah ketimpangan wilayah dan kesejahteraan masyarakat yang rendah. Kabupaten Lombok Timur merupakan wilayah pesisir yang memiliki potensi perikanan yang sangat besar. Hal ini ditandai oleh luas wilayah laut yang mencapai $1.0743,33 \mathrm{~km}^{2}$,
}

yang merupakan 40,09\% dari luas wilayahnya. Permasalahan yang kerap kali dihadapi oleh para nelayan dan pembudi daya di Indonesia khususnya di Kabupaten Lombok Timur adalah kurangnya akses terhadap sumber permodalan yang akan digunakan untuk kegiatan usaha dan akses terhadap teknologi, serta organisasi yang masih lemah yang pada akhirnya rentan mengakibatkan kemiskinan bagi para nelayan dan pembudi daya.

Kondisi ini kerap kali dialami oleh para nelayan dan pembudi daya yang mayoritas berada di wilayah pesisir yang mayoritas mata pencahariannya pada sektor perikanan yang pendapatannya tidak menentu dan kehidupan yang layak (Indarti \& Wardana, 2013). Pemecahan terhadap permasalahan permodalan khususnya bagi nelayan dan pembudi daya telah dicanangkan oleh pemerintah secara khusus melalui program pembangunan ekonomi nasional berbasis perikanan dan perdesaan. Salah satu usaha pemerintah dalam hal ini Kementerian Kelautan dan Perikanan (KKP) untuk menanggulangi permasalahan keterbatasan permodalan yang kerap terjadi pada nelayan dan pembudi daya di perdesaan adalah dengan melakukan program pemberdayaan kepada kelompok nelayan dan kelompok pembudi daya. Pada dasarnya, program bantuan langsung pada masyarakat kelautan dan perikanan telah dilakukan oleh Kementerian Kelautan dan Perikanan melalui Program Nasional Pemberdayaan Masyarakat Mandiri Kelautan dan Perikanan (PNPM Mandiri KP) sejak tahun 2010. PNPM Mandiri KP adalah program pembangunan yang diharapkan dapatmeningkatkan kesejahteraan masyarakat kelautan dan perikanan, sekaligus memupuk jiwa kewirausahaan untuk meningkatkan kemampuan ekonomi keluarga.

Program pemberdayaan masyararakat khususnya untuk nelayan dan pembudi daya ikan di Kabupaten Lombok Timur telah berjalan sejak tahun 2010 (Dinas Kelautan dan Perikanan, Kabupaten Lombok Timur, 2015). Program pemberdayaan yang dilakukan adalah dalam bentuk pelatihan teknologi usaha, bantuan sarana penangkapan ikan dan perlengkapan usaha budi daya laut serta benih. Adanya program tersebut diharapkan usaha perikanan yang dilakukan oleh masyarakat dapat menjadi usaha yang layak dan dapat meningkatkan kesejahteraan (Widiarto, Musa, \& Sumantadinata, 2013; Wantah, 2017). Menurut Hikmat (2006), program ini akan berhasil jika komunikasi program dapat berjalan secara efektif yang ditandai oleh kesesuaian antara aturan yang ditetapkan dengan 
pelaksanaannya di lapangan. Selain itu, faktor karakteristik penerima bantuan menjadi salah satu faktor penentu suksesnya implementasi program bantuan yang disalurkan oleh pemerintah (Anwar, Ati, \& Pindahanto, 2020). Oleh karena itu, strategi pemberdayaan masyarakat melalui berbagai macam program bantuan harus dilakukan dengan tepat agar memberikan dampak pada peningkatan pendapatan (Yunus, 2019). Program bantuan pemerintah di setiap negara pada umumnya bertujuan untuk mengurangi ketimpangan dan jumlah kemiskinan (Gao, 2017). Namun, hal ini dapat menjadi kontradiktif karena adanya program bantuan pemerintah telah menjadikan masyarakat miskin menjadi ketergantungan (Wagaman, Compton, \& Segal, 2018). Berdasarkan paparan di atas, maka diperlukan sebuah kajian yang dapat mengukur kinerja dan efektivitas dari program bantuan pemerintah, khususnya pada PNPM Mandiri KP yang telah bergulir sejak tahun 2010 di Kabupaten Lombok Timur. Penelitian ini dilakukan dengan tujuan (1) menggambarkan pelaksanaan program bantuan perikanan yang disalurkan di Kabupaten Lombok Timur; serta (2) menganalisis kinerja dan efektivitas program tersebut. Diharapkan penelitian ini dapat menjadi bahan pertimbangan bagi pengambil kebijakan ke depannya yang dapat diterapkan pada wilayah lain di Indonesia yang memiliki karakteristik yang sama.

\section{Pendekatan IImiah}

Penelitian ini dilaksanakan pada tahun 2016 di Kabupaten Lombok Timur. Lombok Timur dipilih menjadi lokasi penelitian dengan pertimbangan sebagai lokasi yang mendapatkan bantuan Kementerian Kelautan dan Perikanan program perikanan tangkap dan budi daya tahun 2015 dan berlanjut di tahun 2016. Data primer dikumpulkan melalui wawancara dengan alat bantu kuesioner. Wawancara dilakukan pada empat kelompok nelayan dan tiga kelompok pembudi daya yang menerima program bantuan ini. Total jumlah responden penerima bantuan perikanan tangkap adalah sebanyak 40 orang dan untuk responden penerima bantuan perikanan budi daya adalah 30 orang. Pada penelitian ini juga dilakukan Focus Group Discussion (FGD) yang bertujuan untuk mengeksplorasi masalah yang spesifik, yang berkaitan dengan topik yang dibahas. Teknik ini digunakan dengan tujuan untuk menghindari pemaknaan yang salah dari peneliti terhadap masalah yang diteliti. FGD digunakan untuk menarik kesimpulan terhadap makna-makna intersubjektif yang sulit diberi makna sendiri oleh peneliti karena dihalangi oleh dorongan subjektivitas peneliti (Kresno, Nurlaela, Wuryaningsih \& Ariawan, 1999). FGD merupakan sebuah cara wawancara mendalam yang dilakukan dalam sebuah kelompok yang bertujuan untuk merumuskan sebuah tujuan (Mishra, 2016). Informan kunci yang menjadi peserta dalam FGD ini terdiri dari masing-masing ketua kelompok penerima bantuan, ketua koperasi bahari, unsur dinas kelautan dan perikanan, serta pakar perikanan di lokasi penelitian.

Penelitian ini menggunakan metode penelitian deskriptif kuantitatif. Metode penelitian deskriptif kuantitatif merupakan penelitian yang bermaksud membuat deskripsi atau gambaran melalui pengumpulan fakta-fakta mengenai suatu keadaan. Tujuan dari penelitian deskriptif ini adalah untuk memperoleh gambaran tentang sesuatu dengan jelas terhadap suatu keadaan atau masalah tertentu dengan maksud untuk menguraikan sifat-sifat dari suatu keadaan. Teknik analisis data yang digunakan dalam penelitian ini adalah teknik analisis deskriptif kuantitatif yang digunakan untuk menganalisis persepsi responden (penerima bantuan program bantuan KKP) terhadap implementasi perlindungan nelayan sesuai dengan amanat undang - undang dengan cara membandingkan antara pelaksanaan (fakta) dengan teori yang berkaitan atau harapan dari nelayan. Skor dan kategori dilakukan dengan menggunakan model pendekatan skala likert yang disampaikan oleh Nemoto \& Beglar (2014), dengan rentang 1 sampai dengan 3 . Untuk mengukur jawaban responden, digunakan skala likert yang memiliki bobot dan kategori sebagai berikut:

Tabel 1. Skor dan Kategori Skala Likert yang Digunakan dalam Penelitian.

\begin{tabular}{cc}
\hline Skor & Kategori \\
\hline 1 & Tidak Setuju \\
2 & Kurang Setuju \\
3 & Setuju \\
\hline
\end{tabular}

Sumber: Modifikasi dari Nemoto \& Beglar, 2014

Tahapan selanjutnya adalah pemberian bobot pada masing-masing pertanyaan penelitian, dalam hal ini adalah yang terkait dengan aspek-aspek dalam program pemberdayaan. Pembobotan dilakukan oleh para ahli dengan pendekatan comparative judgement dilakukan dengan membuat penilaian tentang kepentingan relatif dua elemen pada suatu tingkat tertentu dalam kaitannya dengan tingkatan di atasnya. 
Tabel 2. Matriks Perbandingan Berpasangan.

\begin{tabular}{ccccc}
\hline ATRIBUT & $\mathbf{A}_{1}$ & $\mathbf{A}_{2}$ & $\ldots$ & $\mathbf{A}_{\mathrm{n}}$ \\
\hline $\mathrm{A}_{1}$ & $\mathrm{a}_{11}$ & $\mathrm{a}_{21}$ & $\ldots$ & $\mathrm{a}_{1 \mathrm{n}}$ \\
$\mathrm{A}_{2}$ & $\mathrm{a}_{21}$ & $\mathrm{a}_{22}$ & $\ldots$ & $\mathrm{a}_{2 \mathrm{n}}$ \\
$\ldots$ & $\cdots$ & $\cdots$ & $\ldots$ & $\ldots$ \\
$\mathrm{A}_{\mathrm{n}}$ & $\mathrm{a}_{\mathrm{m} 1}$ & $\mathrm{a}_{\mathrm{m} 2}$ & $\ldots$ & $\mathrm{a}_{\mathrm{mn}}$ \\
\hline
\end{tabular}

Metode pairwise comparison digunakan untuk mengetahui keunggulan suatu atribut dibandingkan atribut lainnya sehingga dapat diketahui urutan kepentingan atribut yang diujikan. Langkahnya adalah dengan menentukan susunan prioritas elemen dengan cara menyusun perbandingan berpasangan, yaitu membandingkan dalam bentuk berpasangan seluruh elemen untuk setiap sub hirarki. Perbandingan tersebut ditransformasikan dalam bentuk matriks. Contoh, terdapat nobjek yang dinotasikan dengan (A1, A2,...,An) yang akan dinilai berdasarkan pada nilai tingkat kepentingannya, antara lain Ai dan Aj dipresentasikan dalam matriks pairwise comparison (Tabel 2).

Membuat matriks perbandingan berpasangan memerlukan besaran-besaran yang mampu mencerminkan perbedaan antara faktor satu dengan faktor lainnya. Untuk menilai perbandingan tingkat kepentingan satu kriteria terhadap kriteria lainnya digunakan skala 1 sampai 9. Kriteria yang dibangun merupakan kriteria-kritera dari tujuan capaian dari setiap aspek program bantuan (relevansi, efektivitas, efisiensi, dampak, dan keberlanjutannya). Pendekatan AHP menggunakan skala saaty mulai dari bobot 1 sampai 9, seperti terlihat pada Tabel 3.

\section{POTENSI PERIKANAN KABUPATEN LOMBOK TIMUR}

Kabupaten Lombok Timur masuk ke dalam wilayah Provinsi Nusa Tenggara Barat yang terletak di sebelah timur Pulau Lombok. Lombok Timur memiliki luas wilayah mencapai $1.0743,33 \mathrm{~km}^{2}$, yang merupakan $40,09 \%$ dari luas wilayahnya.
Bentangan pantai mencapai $220 \mathrm{~km}$ dari selatan ke utara. Adapun potensi pengembangan wilayah pesisir dan pulau-pulau kecil mencakup 6 kecamatan serta 22 desa/kelurahan pantai, dengan jumlah nelayan perikanan tangkap sebanyak 16.434 jiwa (BPS, 2011). Potensi perikanan tangkap di Lombok Timur mencapai $12.691,5$ ton per tahun. Tahun 2009 , nilai produksi perikanan tangkap mencapai lebih dari 150 miliar rupiah. Jumlah perikanan tangkap terdiri dari perahu tanpa motor 461 unit, motor tempel 3.123 unit, dan kapal motor 345 unit (BPS, 2010). Daerah penangkapan dari nelayan di Lombok Timur menyebar di Selat Alas, Samudra Hindia, dan Laut Jawa (Gigentika, Wisudo, \& Mustaruddin, 2013). Jenis ikan yang ditangkap mencakup lebih dari lima puluh jenis ikan laut, yang didominasi ikan pelagis besar, seperti cakalang, tuna, dan kelompok ikan demersal, seperti kerapu dan kakap (Husain, 2011; Santoso, 2016; Arnenda \& Rochman, 2019).

Potensi perikanan budi daya di Kabupaten Lombok Timur sangat besar, hal ini terlihat dari berbagai jenis komoditas yang dibudidayakan oleh masyarakat setempat. Berdasarkan hasil penelitian, diketahui ada tiga komoditas utama yang dibudidayakan oleh masyarakat Lombok Timur, yaitu lobster, rumput laut, dan kerang mutiara. Peluang investasi pada budi daya lobster terbuka luas, bukan saja karena permintaan dan harganya tinggi, tetapi juga karena potensi areal pengembangannya yang sangat luas, yaitu mencapai 526,86 ha dan baru dimanfaatkan sebagian kecil saja, yaitu 3,50 ha (Dinas Kelautan dan Perikanan, Kabupaten Lombok Timur, 2015).

Tabel 3. Skala Saaty yang Digunakan dalam Penelitian.

\begin{tabular}{cl}
\hline Tingkat Kepentingan & \multicolumn{1}{c}{ Definisi } \\
\hline 1 & Sama pentingnya dibanding yang lain \\
3 & Moderat (cukup) pentingnya dibanding yang lain \\
5 & Kuat pentingnya dibanding yang lain \\
7 & Sangat kuat pentingnya dibanding yang lain \\
9 & Ekstrim pentingnya dibanding yang lain \\
$2,4,6,8$, & Nilai di antara dua nilai berdekatan \\
Resiprokal & Jika elemen $i$ memiliki salah satu angka di atas ketika dibandingkan \\
& elemen $j$, maka $j$ memiliki kebalikannya ketika dibanding elemen $i$. \\
\hline
\end{tabular}


Budi daya rumput laut memiliki prospek yang cukup bagus mengingat permintaan akan produk ini terus meningkat dari tahun ke tahun. Potensi pengembangan budi daya rumput laut cukup luas, yaitu sekitar 2.000 ha dan baru digunakan 60.471 ha dengan produksi per tahun mencapai 700.000 ton basah sehingga peluang investasi untuk pengembangan budi daya rumput laut ini masih terbuka lebar (Dinas Kelautan dan Perikanan, Kabupaten Lombok Timur, 2009). Potensi pengembangan budi daya mutiara cukup luas, yaitu $2.394,50$ ha dan baru dimanfaatkan $1.962,50 \mathrm{Ha}$ dengan tingkat produksi mencapai 0,20 ton per siklus. Permintaan mutiara produksi Lombok sangat diminati baik oleh pembeli dalam negeri maupun mancanegara karena mutiaranya memiliki keunikan tersendiri yang membedakannya dengan produksi daerah lain. Selain perikanan tangkap dan budi daya perairan pantai Lombok Timur juga memiliki peluang cukup besar untuk pengembangan perikanan air tawar. Dari data yang ada tahun 2008 potensi produksi perikanan sekitar 21.497 ton, dengan potensi terbesar ada di Kecamatan Aikmel, Pringgasela, Masbagik, Selong, dan lainnya (Dinas Kelautan dan Perikanan, Kabupaten Lombok Timur, 2009).

\section{PROGRAM PEMBERDAYAAN MASYARAKAT PERIKANAN}

\section{a. Program pemberdayaan dengan bantuan kapal dan alat tangkap}

Program bantuan kapal dan alat tangkap di Kabupaten Lombok Timur berdasarkan hasil penelitian diketahui diterima pada tahun 2014 dan 2015. Mekanisme penyaluran bantuan dilakukan melalui Dinas Kelautan dan Perikanan Kabupaten Lombok Timur yang disalurkan langsung ke kelompok usaha bersama (KUB). Ada dua lokasi (desa) yang disurvei terkait pemberian bantuan kapal dan alat tangkap, yaitu Desa Tanjung Luar dan Desa Pulau Maringkik. Bantuan yang diterima pada tahun 2014 - 2015 berupa dana (senilai 100 juta rupiah) per KUB, kemudian dana tersebut dikelola oleh masing-masing KUB untuk dibelikan kapal, mesin, dan alat tangkap tergantung masingmasing KUB. Berdasarkan hasil wawancara pendampingan penyaluran dan pemanfaatan bantuan yang dilakukan oleh Dinas Kelautan dan Perikanan sangat intensif. Pemilihan KUB penerima bantuan dilakukan secara menyeluruh mulai dari tahapan identifikasi, verifikasi, dan penetapan. KUB yang terpilih sesuai dengan kategori petunjuk teknis yang telah dibuat oleh Kementerian Kelautan dan Perikanan.

Pemanfaatan bantuan kapal, mesin, dan alat tangkap oleh nelayan anggota KUB sangat berdampak pada peningkatan kesejahteraan. Sebagai contoh, anggota KUB yang sebelumnya tidak memiliki kapal, sekarang mereka telah memiliki kapal menjadi 2 unit dari program bantuan. Hal ini telah menambah aset usaha KUB. Permasalahan terkait penyaluran program bantuan adalah konflik horizontal di kalangan masyarakat bagi yang menerima dan tidak menerima bantuan. Kelompok penerima bantuan memiliki kecenderungan aktif untuk mencari informasi ke Dinas Kelautan dan Perikanan dengan mengirimkan proposal permohonan bantuan. Sementara itu, kelompok yang tidak menerima bantuan cenderung lebih pasif. Hal ini dapat dilihat dari persepsi kelompok yang tidak menerima bantuan yang tidak terbiasa dengan hal yang bersifat administrasi dan tidak memiliki keinginan untuk membentuk kelompok nelayan atau KUB.

Bantuan kapal dan alat tangkap yang ada di Desa Pulau Maringkik diberikan berupa kapal berukuran > 20 GT berbahan fiber. Bantuan tersebut diterima pada bulan Desember tahun 2015, tetapi kapal tersebut belum pernah digunakan sejak diterima sampai dengan dilakukannya penelitian ini. Permasalahannya adalah alat tangkap yang diberikan tidak sesuai dengan jenis kapal yang diterima. Selain itu, surat izin kapal yang sudah melewati masa berlakunya. Surat izin kapal yang diterima bersifat sementara dan berakhir pada bulan Maret 2016 dan pada waktu yang sama nelayan atau kelompok penerima bantuan sudah melakukan permohonan perpanjangan surat melalui Dinas Kelautan dan Perikanan namun belum juga terbit surat perpanjangannya. Akibatnya, nelayan tidak berani pergi menangkap ikan. Nelayan juga bersepakat untuk berswadaya membeli alat tangkap setelah surat izin keluar. Oleh karena itu, nelayan menyimpulkan bahwa bantuan kapal tersebut kurang bermanfaat dan tidak sesuai dengan kebutuhan nelayan. Nelayan lebih cenderung untuk menerima bantuan kapal dengan ukuran yang lebih kecil dan terbuat dari kayu. Ketersediaan bahan bakar dan minyak (BBM) untuk nelayan sangat terbatas sehingga permasalahan ini menjadi salah satu potensi yang menyebabkan program bantuan tidak maksimal. 


\section{b. Program pemberdayaan bantuan excavator}

Program bantuan excavator yang ada di Kabupaten Lombok Timur berjumlah satu unit. Pengelolaan excavator tersebut dikelola oleh Dinas Pekerjaan Umum (Dinas PU). Hasil wawancara dengan Kepala Dinas Kelautan dan Perikanan Kabupaten Lombok Timur dikatakan bahwa pengelolaan excavator di Dinas PU berdasarkan kebijakan kepala daerah dalam hal ini adalah Bupati. Beberapa pertimbangan pengelolaan tersebut di Dinas PU dikarenakan biaya pemeliharaan dan perawatan excavatoryang sangat tinggi sehingga diserahkan ke Dinas PU yang memiliki biaya perawatan terkait alat berat. Selain itu, secara khusus operator excavator belum tersedia. Mekanisme peminjaman excavator oleh pelaku usaha perikanan (pembudi daya) dilakukan dengan cara mengirimkan surat permohonan terlebih dahulu ke Dinas Kelautan dan Perikanan dan selanjutnya Dinas Kelautan dan Perikanan akan menembuskan surat tersebut ke Dinas PU.

Hasil wawancara dengan salah satu pembudi daya dikatakan bahwa pembudi daya (tambak udang) telah mengetahui keberadaan excavator dari bantuan KKP dari sesama petambak udang di Kabupaten Lombok Tengah dan pembudi daya tersebut telah mengirimi surat peminjaman ke Dinas KP tetapi belum ada tanggapan. Hasil kesimpulan sementara terkait excavator adalah Dinas KP belum melakukan sosialisasi kepada pembudi daya atau pelaku usaha perikanan sehingga tidak semua mengetahui pemanfaatan excavator tersebut. Bantuan excavator dinilai sangat sesuai dengan kondisi perikanan di Kabupaten Lombok Timur, karena bermanfaat untuk perluasan atau pengembangan lahan tambak budi daya udang. Berdasarkan hasil penelitian diketahui bahwa penyedia jasa excavator di Lombok Timur cukup banyak. Harga sewa per jam berkisar antara Rp500.000,00 - Rp600.000,00 per jam.

\section{c. Program pemberdayaan bantuan keramba jaring apung}

Program bantuan keramba jaring apung (KJA) High Density Polyethylene (HDPE) pada tahun 2015 difokuskan di Desa Pulau Maringkik. Masyarakat desa ini dikenal sebagai pembudi daya dengan jenis komoditas lobster dan kerapu. Kelompok penerima bantuan terdiri dari 2 kelompok pembudi daya ikan (Pokdakan) yang terdiri dari 10 orang masing-masing pokdakan. Selain pembudi daya ikan, para penerima bantuan juga merupakan nelayan. Bantuan KJA dinilai sesuai dengan kondisi masyarakat. Penerima bantuan yang terpilih telah dilakukan identifikasi dan verifikasi oleh Dinas Kelautan dan Perikanan. Permasalahan terkait budi daya KJA adalah rendahnya harga jual ikan dan lobster hasil budi daya. Hal ini tidak seperti beberapa tahun sebelumnya ketika belum dikeluarkannya Peraturan Menteri Kelautan dan Perikanan terkait pengaturan jual beli lobster (PermenKP Nomor 56 Tahun 2016) dan pelarangan kapal transhipment (PermenKP Nomor 57 Tahun 2014). Komoditas budi daya yang dilakukan oleh masyarakat merupakan komoditas ekspor, namun saat ini hanya dijual di lokal saja dengan harga yang lebih rendah.

\section{KINERJA PROGRAM PEMBERDAYAAN PERIKANAN TANGKAP DAN BUDI DAYA}

Kinerja program pemberdayaan seperti bantuan untuk usaha perikanan tangkap (bantuan kapal dan alat tangkap) dan usaha perikanan budi daya (bantuan excavator dan keramba jaring apung) di Kabupaten Lombok Timur memberikan gambaran secara umum keberhasilan program pemberdayaan yang ada di lokasi tersebut. Kinerja program pemberdayaan diukur berdasarkan lima aspek, yaitu relevansi, efektivitas, efisiensi, dampak, dan keberlanjutan. Pada Tabel 4 disajikan nilai dan kriteria dari kinerja program pemberdayaan perikanan di Kabupaten Lombok Timur yang dilihat dari lima aspek.

Penilaian Kinerja program bantuan akan dibahas berdasarkan lima aspek, yaitu relevansi, efektivitas, efisiensi, dampak, dan keberlanjutan. Secara rinci akan dibahas sebagai berikut.

\section{a. Aspek Relevansi}

Relevansi program dapat dilihat dari tiga indikator, yaitu kepentingan, prioritas, dan kesesuaian. Berdasarkan hasil perhitungan (Tabel 4) diketahui bahwa secara keseluruhan bahwa program pemberdayaan perikanan tangkap sudah sesuai atau relevan dengan kepentingan penerima bantuan di lokasi penelitian. Program ini sudah mencapai target jumlah penerima bantuan maupun sesuai dengan program prioritas pemerintah daerah.

Terkait dengan relevansi program pemberdayaan perikanan tangkap (bantuan kapal dan alat tangkap) hal ini sangat ditentukan oleh kesesuaian program bantuan dengan program dan kebijakan pemerintah daerah. Hal ini menunjukkan 
Tabel 4. Nilai dan Kriteria Aspek Kinerja Program Pemberdayaan Perikanan Tangkap dan Budi Daya di Kabupaten Lombok Timur, 2016.

\begin{tabular}{cccccc}
\hline \multirow{2}{*}{ No } & \multirow{2}{*}{ Aspek } & \multicolumn{2}{c}{ Pemberdayaan Perikanan Tangkap } & \multicolumn{2}{c}{ Pemberdayaan Perikanan Budi Daya } \\
\cline { 2 - 5 } & & Nilai & Kriteria & Nilai & Kriteria \\
\hline 1 & Relevance & 0,4634 & Relevan & 0,3230 & Cukup Relevan \\
2 & Effectiveness & 0,3751 & Cukup Efektif & 0,4825 & Efektif \\
3 & Efficiency & 0,0763 & Cukup Efisien & 0,0930 & Efisien \\
4 & Impact & 0,4231 & Cukup Berdampak & 0,4710 & Cukup Berdampak \\
5 & Sustainability & 0,7521 & Cukup Berkelanjutan & 0,5840 & Tidak Berkelanjutan \\
& Status Keberhasilan & $\mathbf{2 , 0 9 0 0}$ & Cukup Berhasil & $\mathbf{1 , 9 5 3 6}$ & Cukup Berhasil \\
\hline
\end{tabular}

Sumber: Data Diolah, 2016.

\section{Keterangan :}

Selang Nilai Kriteria Relevansi: Tidak Relevan : <0,2998

Cukup Relevan : 0,2998 - 0,4197

Relevan : > 0,4196

Selang Nilai Kriteria Dampak:

Tidak Berdampak : <0,5135

Cukup Berdampak : 0,5135 - 0,6608

Berdampak : > 0,6608
Selang Nilai Kriteria Efektivitas:

Tidak Efektiv : < 0,4644

Cukup Effektiv : 0,4644 - 0,5971

Efektif : >0,5971

Selang Nilai Kriteria Berkelanjutan:

Tidak Berkelanjutan : <0,6060

Cukup Berkelanjutan : 0,6060 - 0,8484

Berkelanjutan : > 0,8484
Selang Nilai Kriteria Efisiensi: Tidak Efisien : < 0,0870

Cukup Efisien : 0,0870 - 0,1119

Efisien : > 0,1119

Selang Nilai Kriteria Berhasil:

Tidak berhasil : < 1,6667

Cukup berhasil : 1,6667 - 2,333

Berhasil : > 2,333 bahwa keberhasilan program bantuan kapal dan alat tangkap dari Kementerian Kelautan dan Perikanan perlu didukung oleh pemerintah daerah agar tujuannya tercapai. Hal ini dapat dilihat dari masing-masing nilai indikator yang lebih besar dibandingkan indikator lainnya. Aspek relevansi pada program pemberdayaan perikanan budi daya (bantuan excavator) mempunyai nilai relevansi lebih rendah dibandingkan pada program pemberdayaan perikanan tangkap, hal ini lebih besar dipengaruhi oleh kebutuhan utama para pelaku usaha budi daya perikanan yang kaitannya dengan kebutuhan sarana input. Penggunaan excavator lebih banyak digunakan untuk memperluas lahan tambak sedangkan para pembudi daya di Kabupaten Lombok Timur lebih banyak yang memanfaatkan lahan tambak yang sudah ada dibandingkan untuk memperluas lahan budi daya. Program bantuan yang sesuai memiliki tingkat keberhasilan yang lebih tinggi dan dapat memberikan dampak positif seperti peningkatan pendapatan (Putra \& Saskara, 2013).

Hal yang menarik terkait aspek relevansi program bantuan kapal dan alat tangkap adalah berdasarkan penilaian bahwa penerima bantuan haruslah pelaku utama. Faktor kebutuhan stakeholders menjadi prioritas berikutnya. Hal ini memiliki makna bahwa penerima bantuan diharapkan adalah nelayan atau kelompok yang memang memiliki pengalaman dalam hal menangkap ikan di laut secara langsung. Penerima bantuan terkait dengan relevansi program adalah harus nelayan yang telah berpengalaman minimal 3 tahun atau menjadi bagian dari kelompok nelayan dan dapat membina anggota lainnya. Kecenderungan kegagalan sangat besar jika penerima bantuan adalah juragan darat dan bukan penangkap ikan sehari-hari (mata pencaharian utama). Meskipun kelompok tersebut membutuhkan kapal dan alat tangkap namun tetap perlu dipertimbangkan keahlian dalam kelompok tersebut dalam hal mengoperasikan armada penangkapan ikan. Relevansi tidak hanya terbatas pada tujuan program dan kebutuhan penerima bantuan, namun juga menyangkut karakteristik penerima bantuan tersebut. Bahkan menurut Parra-Cardona et al. (2012), relevansi budaya menjadi faktor penentu keberhasilan sebuah program atau intervensi pemerintah. Relevansi budaya menjadi faktor penentu bagaimana masyarakat dapat beradaptasi terhadap program yang diimplementasikan.

\section{b. Aspek Efektivitas}

Efektivitas program pemberdayaan dapat dilihat dari lima indikator, antara lain tujuan, maksud, output, aktivitas, dan input. Hasil penilaian menunjukkan bahwa kriteria efektivitas program pemberdayaan perikanan tangkap (bantuan kapal dan alat tangkap) masuk ke dalam kriteria "Cukup Efektif" dan untuk program pemberdayaan perikanan budi daya (bantuan excavator) masuk ke dalam kriteria "Efektif". 
Meskipun bantuan excavator tidak memiliki relevansi yang tinggi, namun memiliki efektivitas yang baik dalam memperluas lahan budi daya. Penggunaan excavator untuk perbaikan dan perluasan lahan tambak lebih efektif dibandingkan menggunakan tenaga manusia. Meskipun demikian penggunaannya masih terbatas dan banyak digunakan oleh pelaku usaha yang memiliki kemampuan finansial yang baik. Kemampuan finansial menurut beberapa peneliti (Indriyatni, 2013; Gasanov, Lisitskaya, Kovaleva, Maziy, \& Mitina, 2019) memiliki dampak yang linier terhadap keberhasilan sebuah usaha agribisnis termasuk di dalamnya bidang perikanan. Aktifitas program yang sudah efektif hal ini menunjukkan bahwa program bantuan yang disalurkan sudah tepat sasaran, tepat waktu, dan teknologi yang diberikan mudah digunakan. Tepat sasaran dapat berarti sudah tepat dalam pemilihan lokasi penerimanya dan pihak penerimanya. Tepat waktu dapat berarti bahwa program bantuan yang disalurkan tepat waktu dalam penyalurannya atau sesuai dengan perencanaannya sesuai tahun berjalan dan datang pada saat dibutuhkan oleh pengguna. Indikator output yang efektif hal ini menunjukkan bahwa program bantuan kapal dan alat tangkap yang telah disalurkan dapat meningkatkan produksi, skala usaha, teknologi yang digunakan sangat adaptif, dan ketrampilan usaha.

\section{c. Aspek Efisiensi}

Efisiensi program pemberdayaan dapat dilihat dari empat indikator, antara lain capaian output, hubungan kausalitas, ketepatan waktu, dan kewajaran biaya. Aspek efisiensi ini lebih menggambarkan biaya atau korbanan dalam menyalurkan program bantuan. Semakin rendah biaya dalam proses penyaluran dan pencapaian tujuan program bantuan maka akan efisien. Program pemberdayaan perikanan tangkap masuk ke dalam kriteria cukup efisien dan untuk program pemberdayaan perikanan budi daya masuk ke dalam kategori efisien. Perbedaan keduanya dipengaruhi oleh biaya yang dikeluarkan dari penerima program. Penerima program bantuan kapal dan alat tangkap mengeluarkan biaya yang lebih tinggi dibandingkan dengan menggunakan kapal dan alat tangkap yang dimiliki sebelumnya dan untuk penerima program bantuan excavator mengeluarkan biaya yang lebih rendah karena dengan adanya program bantuan excavator tidak perlu mengeluarkan biaya sewa excavator dan hanya mengeluarkan biaya operator mesin dan bahan bakar saja.
Hal ini tentu saja menjadi lebih meringankan para pembudi daya. Menurut Yun (2014), pertimbangan efisiensi dalam sebuah program pemberdayaan sangat penting dalam menentukan keberhasilan penyaluran program bantuan dari pemberi kepada penerima bantuan. Aspek efisiensi menjadi sebuah instrumen kontrol oleh pengawas atau pemberi bantuan untuk melihat berhasil atau tidaknya pelaksanaan program dan implementasinya (Alda \& Cuesta, 2019). Program bantuan yang memiliki biaya penyaluran dan operasional aset bantuan yang lebih tinggi memiliki resiko kegagalan yang lebih besar dibandingkan dengan program yang memiliki biaya yang lebih rendah.

\section{d. Aspek Dampak}

Dampak program pemberdayaan dapat dilihat dari tiga indikator, yaitu capaian dampak tujuan keseluruhan, dampak hubungan kausalitas, dan efek pengganda. Indikator dampak tujuan keseluruhan dan efek pengganda masuk dalam kategori tidak berdampak. Hal ini dikarenakan sulit melakukan pengukuran dalam waktu singkat karena indikator ini adalah dampak dalam jangka panjang. Terdapat beberapa persyaratan dalam mengukur dampak sebuah program, di antaranya adalah tenggang waktu pelaksanaan program dan ruang lingkup program tersebut (Wang \& Degol, 2016). Berbeda dengan dampak hubungan kausalitas yang secara singkat dapat diukur, dampak ini tercermin dari produktivitas, pendapatan, lapangan usaha, dan serapan tenaga kerja. Dari ketiga indikator pada aspek dampak diketahui berdasarkan penilaian pengaruh terbesar adalah indikator dampak hubungan sebab-akibat.

Dampak program pemberdayaan pada keduanya memiliki kriteria cukup berdampak, khususnya pada skala mikro di lokasi penelitian atau tingkat penerima bantuan saja dan belum memberikan angka yang signifikan terhadap peningkatan produksi secara regional. Aspek dampak secara keseluruhan berdasarkan penilaian masuk ke dalam kriteria "Cukup Berdampak". Terkait aspek dampak tujuan secara keseluruhan dan efek pengganda cukup sulit untuk dilakukan pengukurannya. Penelitian ini mengukur berdasarkan keterkaitan pada prospek kebijakan daerah, pembangunan daerah, dan faktor penghambat. Faktor prospek diketahui memiliki nilai yang lebih besar dibanding faktor lainnya. Hal ini menunjukkan bahwa dalam dampak tujuan secara keseluruhan program bahwa 
pengembangan usaha melalui sarana bantuan yang diberikan memiliki peluang pengembangan yang besar di setiap lokasi penerima bantuan namun masih memiliki hambatan dalam pelaksanaannya. Program bantuan kapal dan alat tangkap belum mampu secara signifikan untuk mengurangi hambatan dalam rangka peningkatan kesejahteraan. Hal ini disebabkan dalam pengoperasian kapal dan alat tangkap dari program bantuan mengalami hambatan terkait dengan perizinan atau PAS Kecil kapal'. Pengukuran dampak dari program bantuan ini menjadi salah satu faktor penting bagi para pengambil kebijakan sebagai bahan pertimbangan untuk perbaikan atau penerapan kebijakan selanjutnya, bahkan indikator dampak ini selalu menjadi satu acuan berhasil tidaknya suatu program (McDavid, Huse, \& Hawthorn, 2018).

\section{e. Aspek Keberlanjutan}

Keberlanjutan program pemberdayaan dapat dilihat dari empat indikator, yaitu kebijakan dan sistem, organisasi dan keuangan, teknologi dan masyarakat, serta budaya dan lingkungan. Dari keempat indikator tersebut diketahui bahwa indikator masyarakat, budaya, dan lingkungan memiliki nilai yang paling besar. Secara umum, program pemberdayaan perikanan tangkap masuk ke dalam kategori cukup berkelanjutan dan untuk program pemberdayaan perikanan budi daya masuk ke dalam kriteria tidak berkelanjutan. Peluang pemerintah daerah untuk melanjutkan program bantuan kapal dan alat tangkap serta bantuan excavator melalui APBD memiliki peluang cukup kecil. Hal ini dikembalikan kepada program prioritas masing-masing di daerah. Sebagai contoh Kabupaten Lombok Timur, program prioritas lebih kepada budi daya rumput laut karena untuk mendukung program prioritas NTB, yaitu PIJAR (Sapi Jagung dan Rumput Laut). Artinya program peningkatan produksi perikanan tangkap di Kabupaten Lombok Timur tidak segencar peningkatan produksi rumput laut.

Berdasarkan penilaian tersebut diketahui bahwa kebijakan dan sistem (peraturan dan pemerintahan) yang ada di lokasi penerima bantuan belum mendukung keberlanjutan program bantuan ini. Indikator teknologi pun menjadi hal yang penting untuk diperhatikan dalam mewujudkan keberlanjutan program bantuan kapal dan alat tangkap. Teknologi yang diberikan haruslah mudah dipahami dan juga murah atau mudah dijangkau oleh nelayan. Indikator keuangan dan organisasi menunjukkan bahwa program bantuan kapal dan alat tangkap memiliki kriteria tidak berkelanjutan. Beberapa lokasi terpilih secara kelompok belum bisa mandiri untuk memenuhi kecukupan anggaran dalam menjalankan usaha penangkapan dan masih membutuhkan bantuan dari pedagang pengumpul sebagai sumber modal. Hal ini sejalan dengan pernyataan Wang, Hawkins, Lebredo, \& Berman (2012), bahwa kondisi finansial atau anggaran memiliki pengaruh terhadap keberlanjutan, dengan tingkat keberlanjutan tinggi selalu didukung oleh ketersediaan anggaran yang memadai. Menurut Adams, Muir, \& Hoque (2014), pengukuran status keberlanjutan program menjadi pertimbangan untuk perbaikan penyaluran program selanjutnya.

\section{PENUTUP}

Kinerja program pemberdayaan perikanan tangkap dan budi daya di Kabupaten Lombok Timur dapat dikatakan cukup berhasil. Aspek dampak dan keberlanjutan program memiliki pengaruh yang besar terhadap keberhasilan atau pencapaian tujuan program. Rekapitulasi penilaian kinerja program pemberdayaan perikanan tangkap adalah relevan, cukup efektif, cukup efisien, cukup berdampak, dan cukup berkelanjutan. Jadi, secara keseluruhan kinerja program pemberdayaan perikanan tangkap adalah cukup berhasil. Penilaian kinerja program pemberdayaan perikanan budi daya adalah cukup relevan, efektif, efisien, dan cukup berdampak namun tidak berkelanjutan. Kinerja program pemberdayaan perikanan budi daya adalah cukup berhasil. Hasil analisis menunjukkan bahwa setiap program pemberdayaan dengan mekanisme pemberian bantuan sarana usaha akan memberikan dampak keberhasilan yang berbeda pula baik untuk setiap jenis bantuan maupun berdasarkan lokasinya.

Agar dampak program-program pemberdayaan di masa yang akan datang kinerjanya lebih optimal, sebaiknya hasil penelitian ini dapat dijadikan bahan masukkan dan memberikan implikasi baik terhadap

1PAS Kecil adalah Surat Tanda Kebangsaan Kapal untuk kapal bertonase kurang dari GT 7. Umumnya adalah kapal tradisional dan kapal nelayan. 
pemberi bantuan maupun penerima bantuan. Oleh karena itu, Program bantuan ke depan lebih memperhatikan lokasi bantuan dan calon penerima bantuan. Lokasi bantuan diutamakan merupakan sentra mata pencaharian utamanya adalah usaha perikanan. Calon penerima bantuan sebaiknya dipilih dengan kriteria inovator atau "early adopter"

Perlu dilakukan sinkronisasi program antara pemerintah pusat dan pemerintah daerah terutama program peningkatan kapasitas usaha dari pelaku usaha.Peningkatan manfaat dan dampak program bantuan tidak terlepas dari peran pemerintah daerah untuk mengawasi, memonitoring, serta pelaporan kinerjanya. Ke depan, perlu peningkatan peran terutama yang terkait langsung dengan program bantuan KKP, yaitu Dinas Perikanan dan Kelautan kabupaten/ kota, serta Dinas Koperasi dan UMKM. Masingmasing institusi tersebut berperan sesuai dengan tugas dan fungsinya. Pelaku usaha perlu berupaya belajar dan bertanggung jawab terhadap bantuan yang diberikan serta dapat mengoptimalisasi kan pemanfaatan bantuan KKP, sehingga pada akhirnya terjadi peningkatan dalam usahanya.

\section{UCAPAN TERIMAKASIH}

Penulis mengucapkan terima kasih kepada Balai Besar Riset Sosial Ekonomi Kelautan dan Perikanan (BBRSEKP) yang telah memberikan kesempatan kepada penulis dan tim untuk melakukan kegiatan penelitian di Kabupaten Lombok Timur pada tahun 2016. Selain itu, ucapan terima kasih juga kami sampaikan kepada seluruh tim lapang yang terlibat pada penelitian ini yang terdiri dari unsur Dinas Kelautan dan Perikanan, penyuluh perikanan bantu, dan semua penerima bantuan yang menjadi responden penelitian ini.

\section{PERNYATAAN KONTRIBUSI PENULIS}

Dengan ini kami menyatakan bahwa kontribusi penulis dalam pembuatan karya tulis adalah Maulana Firdaus sebagai kontributor utama serta Nensyana Shafitri dan Cornelia Mirwantini Witomo sebagai kontributor anggota. Penulis juga menyatakan bahwa telah melampirkan surat pernyataan kontribusi penulis.

\section{DAFTAR PUSTAKA}

Adams, C. A., Muir, S., \& Hoque, Z. (2014). Measurement of sustainability performance in the public sector. Sustainability Accounting, Management and Policy Journal, 5, 46-67. http://dx.doi. org/10.1108/SAMPJ-04-2012-0018.

Afdillah, Y., Harahap, I., \& Marliyah. (2016). Analisis Tingkat Kesenjangan Pendapatan pada Masyarakat Tebing Tinggi. FEBI UIN-SU Press. ISBN: 978-602-6903-01-3.

Alda, E., \& Cuesta, J. (2019). Measuring the efficiency of humanitarian aid. Economics Letters, 183, 108618.

Anwar, D. P., Ati, N. U., \& Pindahanto, R. (2020). Implementasi Program Bantuan Pangan Non Tunai (BPNT) Dinas Sosial Dalam Menanggulangi Kemiskinan Di Kelurahan Sisir Kecamatan Batu Kota Batu. Respon Publik, 14(3), 1.

[BPS] Badan Pusat Statistik. (2011). Provinsi Nusa Tenggara Barat dalam Angka 2010. Lombok. Badan Pusat Statistik Provinsi Nusa Tenggara Barat.

[BPS] Badan Pusat Statistik. (2010). Kabupaten Lombok Timur dalam Angka 2009. Lombok Timur. Badan Pusat Statistik Provinsi Nusa Tenggara Barat

Arnenda, G. L., \& Rochman, F. (2019). Sebaran daerah penangkapan dan potensi stok sumber daya ikan tuna tongkol cakalang di Labuhan Lombok. Prosiding Seminar Nasional Tahunan Hasil Perikanan dan Kelautan, 16, 274-282.

Aziz, I. J. (1994). Ilmu Ekonomi Regional dan Beberapa Aplikasinya di Indonesia. Jakarta: Lembaga Penerbit FEUI.

Bagchi, S., \& Svejnar, J. (2015). Does wealth inequality matter for growth? The effect of billionaire wealth, income distribution, and poverty. Journal of Comparative Economics, 43(3), 505-530. https:// doi.org/10.1016/j.jce.2015.04.002.

Budianta, A. (2010). Pengembangan wilayah perbatasan sebagai upaya pemerataan pembangunan wilayah di Indonesia. Jurnal SMARTek, 8(1), 72-82. http://jurnal.untad.ac.id/jurnal/index.php/ SMARTEK/article/view/628/546.

Dinas Kelautan dan Perikanan, Kabupaten Lombok Timur, (2009). Laporan Tahunan 2009. Tidak Dipublikasikan. Dinas Perikanan Kabupaten Lombok Timur.

Dinas Kelautan dan Perikanan, Kabupaten Lombok Timur, (2015). Laporan Tahunan 2015. Tidak Dipublikasikan. Dinas Perikanan Kabupaten Lombok Timur.

Gao, Q. (2017). Welfare, work, and poverty: Social assistance in China. Oxford University Press.

Gasanov, O., Lisitskaya, T., Kovaleva, N., Maziy, V., \& Mitina, I. (2019). Formation of funding sources for agribusiness organizations. IOP Conference 
Series: Earth and Environmental Science, 403(1). https://doi.org/10.1088/1755-1315/403/1/012075.

Gigentika, S., \& Wisudo, S. H., Mustaruddin. (2013). Kelayakan Finansial Usaha Perikanan Pancing Tonda di PPP Labuhan Lombok Kabupaten Lombok Timur. Buletin PSP, 21(2), 137-148.

Hikmat, A. (2006). Strategi Pemberdayaan Masyarakat, Humaniora Utama Press Bandung.

Husain, F. (2011). Sistem Budaya Bahari Komunitas Nelayan Lungkak Desa Tanjung Luar, Lombok Timur, Nusa Tenggara Barat. Komunitas: International Journal of Indonesian Society and Culture, 3(1).

Indarti, I., \& Wardana, D. S. (2013). Metode pemberdayaan masyarakat pesisir melalui penguatan kelembagaan pesisir di Kota Semarang. BENEFIT Jurnal Manajemen dan Bisnis, 17(1), 75-88.

Indriyatni, L. (2013). Analisis faktor faktor yang berpengaruh terhadap keberhasilan usaha mikro dan kecil (studi pada usaha kecil di Semarang Barat). Jurnal STIE Semarang, 5(1), 54-70.

Kresno, S.E., Nurlaela, E., Wuryaningsih., \& Ariawan, I. (1999). Aplikasi Penelitian Kualitatif dalam Pencegahan dan Pemberantasan Penyakit Menular. Fakultas Kesehatan Masyarakat Universitas Indonesia bekerja sama dengan Direktorat Jenderal Pemberantasan Penyakit Menular dan Penyehatan Lingkungan Pemukiman Depkes RI. Jakarta.

Mahadevan, R., \& Suardi, S. (2019). Panel evidence on the impact of tourism growth on poverty, poverty gap and income inequality. Current Issues in Tourism, 22(3), 253-264. https://doi.org/10.1080 /13683500.2017.1375901.

Maifizar, A. (2018). Karakteristik dan Fenomena Kemiskinan Keluarga Miskin Pedesaan di Aceh. Community: Pengawas Dinamika Sosial, 2(3).

Maipita, I., Jantan, M. D., \& Razak, N. A. A. (2010). Dampak Kebijakan Fiskal Terhadap Kinerja Ekonomi dan Angka Kemiskinan di Indonesia. Buletin Ekonomi Moneter dan Perbankan Bank Indonesia, 12(4), 421-456. https://doi. org/10.21098/bemp.v12i4.248.

McDavid, J. C., Huse, I., \& Hawthorn, L. R. (2018). Program evaluation and performance measurement: An introduction to practice. Sage Publications.

Mishra, L. (2016). Focus group discussion in qualitative research. TechnoLearn: An International Journal of Educational Technology, 6(1), 1-5.

Nemoto, T., \& Beglar, D. (2014). Likert-scale questionnaires. In JALT 2013 Conference Proceedings, 1-8.
Parra Cardona, J.R., Domenech-Rodriguez, M., Forgatch, M., Sullivan, C., Bybee, D., Holtrop, K., Escobar-Chew, A.R., Tams, L., Dates, B. and Bernal, G. (2012). Culturally Adapting an Evidence-Based Parenting Intervention for $\mathrm{L}$ atino Immigrants: The Need to Integrate Fidelity and Cultural Relevance. Family Process, 51(1), 56-72.

Putra, I., \& Saskara, I. (2013). Efektivitas Dan Dampak Program Bantuan Kredit Usaha Rakyat (Kur) Terhadap Pendapatan Dan Kesempatan Kerja Usaha Mikro Kecil Dan Menengah di Kota Denpasar. E-Jurnal Ekonomi Pembangunan Universitas Udayana, 2(10), 457-468.

Sartika, C., Balaka, M. Y., Rumbia, W. A. (2016). Studi Faktor-Faktor Penyebab Kemiskinan Masyarakat Desa Lohia Kecamatan Lohia Kabupaten Muna. Jurnal Ekonomi, 1(1), 106-118.http://ojs.uho.ac.id/index.php/JE/article/ view/976.

Santoso, D. (2016). Potensi Lestari dan Status Pemanfaatan Ikan Kakap Merah dan Ikan Kerapu Di Selat Alas Propinsi Nusa Tenggara Barat. Jurnal Biologi Tropis, 16(1).

Sholihah, F., \& Kustanto, M. (2017). Pengaruh Pertumbuhan Ekonomi dan Kesenjangan Pendapatan terhadap Kesejahteraan Masyarakat Kabupaten Sidoarjo. Seminar Nasional \& Call for Paper, FEB Unikama "Peningkatan Ketahanan Ekonomi Nasional Dalam Rangka Menghadapi Persaingan Global” Malang, 94-105.

Sumaryadi, I. N. (2005). Perancanaan Pembangunan Daerah Otonom dan Pemberdayaan Masayarakat. Citra Utama. Jakarta.

Wagaman, M. A., Compton, K. S., \& Segal, E. A. (2018). Social empathy and attitudes about dependence of people living in poverty on government assistance programs. Journal of Poverty, 22(6), 471-485.

Wang, M. T., \& Degol, J. L. (2016). School climate: A review of the construct, measurement, and impact on student outcomes. Educational Psychology Review, 28(2), 315-352.

Wang, X., Hawkins, C. V., Lebredo, N., \& Berman, E. M. (2012). Capacity to sustain sustainability: A study of US cities. Public Administration Review, 72(6), 841-853.

Wantah, E. (2017). Pemberdayaan Nelayan Berbasis Pendidikan Ekonomi Dan Potensi Pesisir di Kabupaten Minahasa Utara. Jurnal Teori dan Praksis Pembelajaran IPS, 2(2), 43-51.

Widiarto, S. B., Hubeis, M., \& Sumantadinata, K. (2013). Efektivitas Program Pemberdayaan Usaha 
Garam Rakyat di Desa Losarang, Indramayu. Jurnal Manajemen Pengembangan Industri Kecil Menengah, 8(2), 144-154. https://doi. org/10.29244/mikm.8.2.144-154

Yun, J. (2014). Aid Programs for Higher Education. In Income Contingent Loans, 216-222. Palgrave Macmillan, London.

Yunus, E. Y. (2019). Implementasi Program Bantuan Pangan Non Tunai (BPNT) Di Kecamatan Kanigaran Kota Probolinggo. Jurnal Reformasi, 9(2), 138-152. 
Lampiran 1. Perhitungan Nilai dan Kriteria Aspek Kinerja Program Pemberdayaan Perikanan Tangkap dan Budi Daya di Kabupaten Lombok Timur, 2016.

\begin{tabular}{|c|c|c|c|c|c|}
\hline \multirow{3}{*}{ No } & \multirow{3}{*}{ ISU PERMASALAHAN } & \multicolumn{4}{|c|}{ Program Bantuan Kementerian Kelautan dan Perikanan } \\
\hline & & \multicolumn{2}{|c|}{ Bidang Perikanan Tangkap } & \multicolumn{2}{|c|}{ Bidang Perikanan Budidaya } \\
\hline & & Nilai & Kriteria & Nilai & Kriteria \\
\hline \multirow[t]{9}{*}{1} & Relevance & 0.4634 & Relevan & 0.3230 & Cukup Relevan \\
\hline & 1.1. kepentingan & 0.0285 & Cukup Relevan & 0.0134 & Tidak Relevan \\
\hline & 1.1.1. Sesuai dengan kebutuhan stakeholder & 0.0009 & & 0.0013 & \\
\hline & 1.1.2. Sasaran penerima adalah pelaku utama & 0.0276 & & 0.0121 & \\
\hline & 1.2. prioritas & 0.1655 & Relevan & 0.1986 & Relevan \\
\hline & $\begin{array}{l}\text { 1.2.1. Prioritas kebijakan pembangunan perikanan } \\
\text { Pusat dan Daerah }\end{array}$ & 0.1655 & & 0.1986 & \\
\hline & 1.3. kesesuaian & 0.2694 & Relevan & 0.1111 & Cukup Relevan \\
\hline & 1.3.1. strategi pembangunan perikanan & 0.0110 & & 0.0159 & \\
\hline & 1.3.2. target penerima bantuan & 0.2584 & & 0.0952 & \\
\hline \multirow[t]{24}{*}{2} & Effectiveness & 0.3751 & Cukup Efektif & 0.4825 & Efektif \\
\hline & 2.1. Tujuan & 0.1229 & Cukup Efektif & 0.1713 & Efektif \\
\hline & 2.1.1. Kemudahan akses sumber produksi & 0.0377 & & 0.0588 & \\
\hline & 2.1.2. Membuka lapangan kerja & 0.0637 & & 0.0879 & \\
\hline & 2.1.3. Kemudahan akses iptek & 0.0046 & & 0.0054 & \\
\hline & 2.1.4. Meningkatkan keterampilan usaha & 0.0168 & & 0.0192 & \\
\hline & 2.2. Maksud & 0.1257 & Cukup Efektif & 0.1734 & Efektif \\
\hline & 2.2.1. meningkatkan produktivitas & 0.0615 & & 0.0922 & \\
\hline & 2.2.2. Meningkatkan pendapatan & 0.0450 & & 0.0525 & \\
\hline & 2.2.3. Membuka lapangan usaha & 0.0171 & & 0.0258 & \\
\hline & 2.2.4. Meningkatkan penyerapan tenaga kerja & 0.0021 & & 0.0029 & \\
\hline & 2.3. Output & 0.0521 & Tidak Efektif & 0.0604 & Tidak Efektif \\
\hline & 2.3.1. Menambah sumber produksi & 0.0074 & & 0.0223 & \\
\hline & 2.3.2. meningkatkan skala usaha & 0.0084 & & 0.0142 & \\
\hline & $\begin{array}{l}\text { 2.3.3. Mengembangkan ilmu pengetahuan, teknologi } \\
\text { yang adaptif }\end{array}$ & 0.0273 & & 0.0177 & \\
\hline & 2.3.4. Meningkatkan keterampilan usaha & 0.0090 & & 0.0061 & \\
\hline & 2.4. Aktifitas & 0.0067 & Efektif & 0.0095 & Efektif \\
\hline & 2.4.1. tepat guna (teknologi atau alat yang digunakan) & 0.0047 & & 0.0061 & \\
\hline & 2.4.2. tepat waktu (kapan dilaksanakan) & 0.0017 & & 0.0032 & \\
\hline & 2.4.3. tepat sasaran (siapa yang akan diberi) & 0.0002 & & 0.0002 & \\
\hline & 2.5. Input & 0.0678 & Efektif & 0.0679 & Efektif \\
\hline & 2.5.1. Proses identifikasi calon penerima bantuan & 0.0435 & & 0.0435 & \\
\hline & 2.5.2. Proses seleksi calon penerima bantuan & 0.0226 & & 0.0226 & \\
\hline & 2.5.3. Proses penetapan calon penerima bantuan & 0.0016 & & 0.0017 & \\
\hline \multirow[t]{15}{*}{3} & Efficiency & 0.0763 & Cukup Efisien & 0.0930 & Efisien \\
\hline & 3.1. capaian output & 0.0233 & Tidak Efisien & 0.0324 & Cukup Efisien \\
\hline & 3.1.1 kuantitas output & 0.0013 & & 0.0024 & \\
\hline & 3.1.2 kualitas output & 0.0219 & & 0.0300 & \\
\hline & 3.2. hubungan kausalitas & 0.0311 & Cukup Efisien & 0.0393 & Efisien \\
\hline & 3.2.1 kecukupan input & 0.0192 & & 0.0234 & \\
\hline & 3.2.2. isu terkini & 0.0113 & & 0.0150 & \\
\hline & 3.2.3. inflasi & 0.0006 & & 0.0008 & \\
\hline & 3.3. ketepatan waktu & 0.0202 & Efisien & 0.0202 & Efisien \\
\hline & 3.3.1. kuantitas input & 0.0013 & & 0.0013 & \\
\hline & 3.3.2. kualitas input & 0.0189 & & 0.0189 & \\
\hline & 3.4. kewajaran biaya & 0.0018 & Efisien & 0.0011 & Tidak Efisien \\
\hline & 3.4.1. instalasi & 0.0003 & & 0.0002 & \\
\hline & 3.4.2. perawatan & 0.0004 & & 0.0002 & \\
\hline & 3.4.3. operasional & 0.0010 & & 0.0007 & \\
\hline \multirow[t]{9}{*}{4} & Impact & 0.4231 & Cukup Berdampak & 0.4710 & Cukup Berdampak \\
\hline & 4.1. dampak tujuan keseluruhan & 0.1576 & Cukup Berdampak & 0.2061 & Cukup Berdampak \\
\hline & 4.1.1. prospek & 0.0939 & & 0.1295 & \\
\hline & 4.1.2. pembangunan daerah & 0.0555 & & 0.0687 & \\
\hline & 4.1.3. Faktor penghambat & 0.0082 & & 0.0079 & \\
\hline & 4.2. dampak hubungan kausalitas & 0.1438 & Cukup Berdampak & 0.1349 & Cukup Berdampak \\
\hline & 4.2.1. produktivitas & 0.0660 & & 0.0691 & \\
\hline & 4.2.2. pendapatan & 0.0589 & & 0.0464 & \\
\hline & 4.2.3. lapangan usaha & 0.0149 & & 0.0155 & \\
\hline
\end{tabular}




\section{Lanjutan Lampiran 1.}

\begin{tabular}{|c|c|c|c|c|c|}
\hline \multirow{3}{*}{ No } & \multirow{3}{*}{ ISU PERMASALAHAN } & \multicolumn{4}{|c|}{ Program Bantuan Kementerian Kelautan dan Perikanan } \\
\hline & & \multicolumn{2}{|c|}{ Bidang Perikanan Tangkap } & \multicolumn{2}{|c|}{ Bidang Perikanan Budidaya } \\
\hline & & Nilai & Kriteria & Nilai & Kriteria \\
\hline \multirow{26}{*}{5} & 4.2.4. serapan tenaga kerja & 0.0039 & & 0.0039 & \\
\hline & 4.3. efek pengganda & 0.1217 & Cukup Berdampak & 0.1300 & Cukup Berdampak \\
\hline & 4.3.1. usaha pendukung & 0.0038 & & 0.0074 & \\
\hline & 4.3.2. tenaga kerja & 0.1179 & & 0.1226 & \\
\hline & Sustainability & 0.7521 & Cukup Berkelanjutan & 0.5841 & Tidak Berkelanjutan \\
\hline & 5.1. kebijakan dan system & 0.2157 & Berkelanjutan & 0.1914 & Berkelanjutan \\
\hline & 5.1.1. keberlanjutan kebijakan & 0.1119 & & 0.0786 & \\
\hline & 5.1.2. Ketersediaan regulasi & 0.0368 & & 0.0368 & \\
\hline & 5.1.3. Perencanaan & 0.0602 & & 0.0691 & \\
\hline & 5.1.4. Penyebaran manfaat & 0.0067 & & 0.0069 & \\
\hline & 5.2. organisasi dan keuangan & 0.0259 & Cukup Berkelanjutan & 0.0369 & Berkelanjutan \\
\hline & 5.2.1. Keberlanjutan organisasi & 0.0053 & & 0.0108 & \\
\hline & 5.2.2. Kepemilikan bantuan & 0.0091 & & 0.0136 & \\
\hline & 5.2.3 Kecukupan anggaran & 0.0049 & & 0.0057 & \\
\hline & 5.2.4. Peluang anggaran & 0.0046 & & 0.0042 & \\
\hline & 5.2.6. Ukuran kecukupan anggaran & 0.0021 & & 0.0025 & \\
\hline & 5.3. teknologi & 0.1713 & Tidak Berkelanjutan & 0.1341 & Tidak Berkelanjutan \\
\hline & 5.3.1. Mudah & 0.0515 & & 0.0343 & \\
\hline & 5.3.2. Murah & 0.0330 & & 0.0153 & \\
\hline & 5.3.3. Ramah lingkungan & 0.0480 & & 0.0520 & \\
\hline & 5.3.4. Mekanisme diseminasi & 0.0012 & & 0.0012 & \\
\hline & 5.3.5. Pendampingan teknologi & 0.0130 & & 0.0130 & \\
\hline & 5.3.6. Difusi teknologi & 0.0246 & & 0.0183 & \\
\hline & 5.4. masyarakat, budaya dan lingkungan & 0.3392 & Tidak Berkelanjutan & 0.2217 & Tidak Berkelanjutan \\
\hline & 5.4.1. Karakteristik masyarakat & 0.3197 & & 0.1979 & \\
\hline & 5.4.2. Keberadaan lingkungan & 0.0195 & & 0.0237 & \\
\hline
\end{tabular}

